\title{
EXPERIMENTAL STUDY OF POLLUTION BY OIL AND OIL PRODUCT BATUMI PORT AREA
}

\author{
Mzia Diasamidze, Department of General education disciplines of the Batumi State Maritime \\ Academy, professor, Faculty of Navigation, 6000, Georgia, Batumi, \\ Anna Shotadze, Department of General education disciplines of the Batumi State Maritime Academy, \\ associate Professor, Faculty of Navigation, 6000, Georgia, Batumi,
}

\section{DOI: https://doi.org/10.31435/rsglobal_conf/30062021/7622}

Abstract. As you know Artificial pollution is a serious environmental problem of the Black Sea, which is created by household, industrial, atmospheric and river waste, as well as garbage - intentionally or unintentionally dumped from ships. A significant part of sea transportation is occupied by transportation of energy carriers (crude oil, oil products). This represents our scientific interest as one of the leading maritime academies in the Black Sea basin. Previous studies were devoted to the study of the possible pollution of the Black Sea coast of Adjara by the inflowing rivers, (by 7 components). Our Research was of an experimental nature and was carried out using a multifunctional photometer and bathometer, purchased within the framework of a research project of an internal grant from the Maritime Academy. This study was conducted under the same project, which concerns the most urgent problem of pollution of the Batumi Black Sea water area with oil and oil products. Samples taken in different parts of the water area of Batumi were investigated. Laboratory studies were carried out to determine the content of petroleum products, the results of measurements were obtained. Research has revealed signs of water pollution.

The research results are presented in the form of tables and diagrams, consisting of the studied components. conducted environmental studies are of great practical importance. We are going to continue research in this direction, by comparing the results obtained with previous data and on the basis of causal conclusions, which will make it possible to identify trends in the processes associated with oil pollution of the Black Sea coast. As a consequence, it will be possible to outline and plan preventive measures to protect the environment.

Keywords: Water area of the port of Batumi, pollution by oil and oil products, fractional distillation, waste water.

Little things from history. The history of the Batumi oil terminal dates back to the XIX century and is closely related to the historical events of the development of the oil industry in the Caspian region. By 1876, Ludwig Nobel (founder of the Nobel Brothers) had become the principal oil tycoon of Baku, the Caspian "Black Pearl". In 1883, the Nobel Brotherhood built their first oil depot in Batumi. The history of Batumi Oil Terminal starts from the construction of this facility. In 1883, Baron Alphonse Rothschild financed the construction of a railway from Baku to the port of Batumi. In 1886, the Rothschilds founded the famous Caspian and Black Sea Oil Company, through which oil storage reservoirs and trading enterprises were built on the existing areas of the oil terminal in Batumi. With the new Baku-Batumi railway, Batumi has literally become one of the major oil ports in the world.

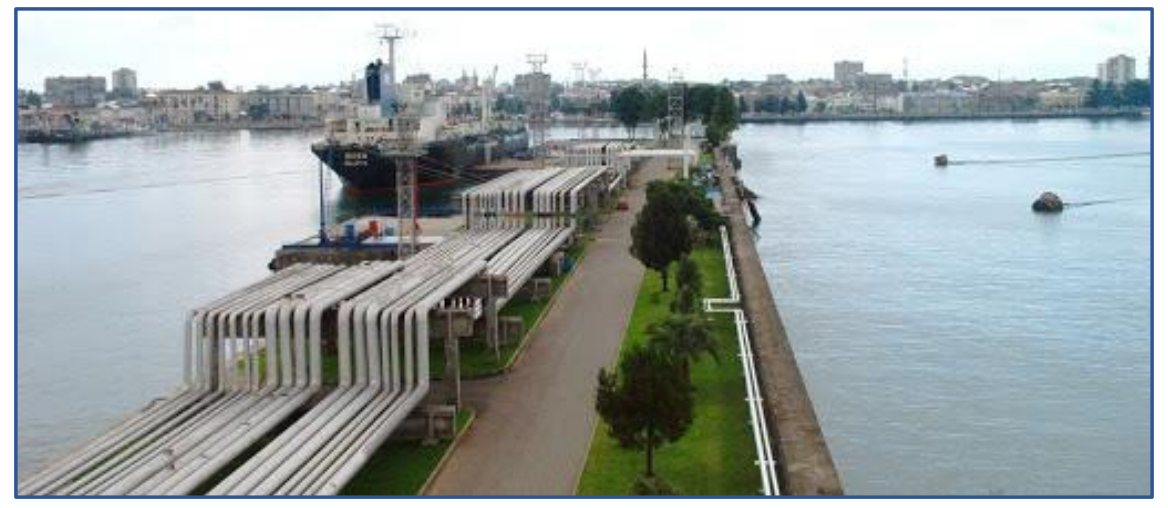

Fig. 1. Batumi oil terminal. 
Shipping through ports, coastal waters and special economic zones, especially oil transportation by tankers, is associated with the risk of marine pollution as a result of possible collisions, accidents, oil overload and bunkering operations and other maritime incidents [3]. Such pollution can endanger recreational areas, sensitive environments, seabirds, marine life, coastal facilities, and fisheries. A large part of maritime shipping is occupied by shipments of energy carriers (crude oil and petroleum products). These purposes are served by two specialized facilities: the Supsa Oil Terminal and the Kulevi Port, as well as specialized terminals in the ports of Poti and Batumi. In turn, this causes pollution of the sea area with petroleum hydrocarbons. Due to the ability of oil and oil products to float on the water surface, coastal beaches are also polluted. The main pollutants are petroleum hydrocarbons. In this regard, the so-called. The "hot spot" is the coast of Adjara, in particular the water area of Batumi.

Batumi, Kobuleti, Poti, Ureki, Anaklia - are famous resort cities in the Black Sea basin. At least $50 \%$ of its population lives in the coastal zone. Added to this is a significant increase in coastal population during the holiday season. The role of shipping in global transport systems is growing. The so-called the vector of most of the "transport corridors" is directed towards the sea, which, in turn, leads to an increase in the cargo turnover of ports. This in turn leads to an increase in coastal pollution.

The attractiveness of Georgia's coastal zone and the strengthening of its economic potential are linked to the intensive consumption of natural resources in this zone. Therefore, knowledge of the potential of existing natural complexes and the current ecological condition of the environment is very important for achieving the goal of sustainable development of the coastal zone [4]. The pollution of the Black Sea environment is also facilitated by the accumulation processes that take place due to the limited exchange with other oceanic waters. Despite the multifaceted measures taken in the field of ecological protection of the Black Sea, interest and research are urgent in identifying sources of marine pollution and taking preventive measures.

Oil extraction, reloading and refining operations have been carried out in Batumi for a long time. Currently operating Batumi Oil Terminal provides services for the reloading of crude oil, petroleum products and liquefied hydrocarbon gas. In addition to the ongoing oil-related operations in the port of Batumi, the current unfavorable situation is significantly due to the historical pollution on the former territory of the Batumi oil refinery. The rivers Korolistskali and Bartskhana, in the direction of which the groundwater is discharged from the territory of the former oil refinery in Batumi, are practically a permanent source of hydrocarbon pollution Black Sea with oil.

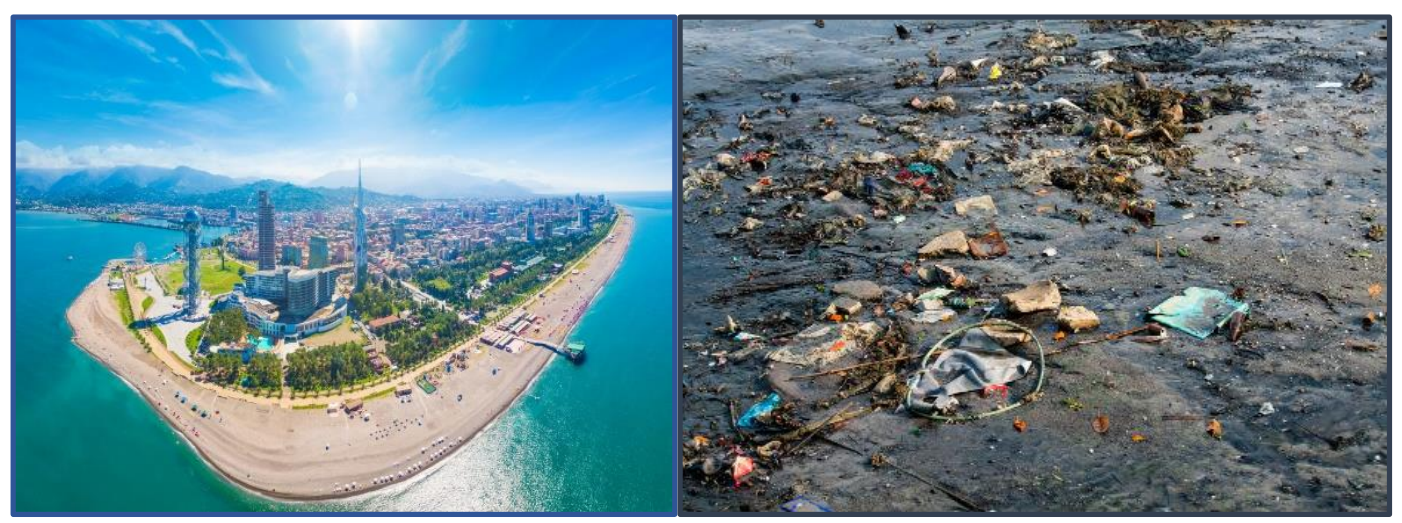

Fig. 2. pollution of coastal areas of Batumi.

The composition of the industrial waste differs significantly from household. Table 1 shows data on the maximum permissible concentrations of oil products in wastewater.

Table 1. Maximum Allowable Concentration petroleum products in wastewater

\begin{tabular}{|l|l|c|}
\hline$№$ & \multicolumn{1}{|c|}{ These norms are strictly regulated and have the following meanings: } & $\mathrm{mg} / \mathrm{L}$ \\
\hline 1 & Maximum permissible concentration a lot of sulphurous oil in the drains & 0,1 \\
\hline 2 & The maximum permissible concentration in wastewater of other types of oil & 0,3 \\
\hline 3 & The maximum permissible content of gasoline in wastewater & 0,1 \\
\hline 4 & The maximum permissible concentration of technical, oxidized, tractor kerosene & 0,01 \\
\hline 5 & The limiting value of the content of lighting kerosene & 0,05 \\
\hline 6 & Maximum allowable concentration of sulfated kerosene in drains & 0,1 \\
\hline
\end{tabular}


We decided to study the Black Sea (Batumi and its vicinities) Pollution point and diffuse sources. Point sources - the discharge of polluted water from factories through pipes into rivers and then into the sea in this way. Diffuse sources - simultaneous pollution of various facilities at multiple points through drainage water generated by rains (which is abundant in Adjara). For this purpose, we carried out field I and field II field trips at the confluence of rivers and various points of Batumi water area. We took water samples at different points in sunny and rainy weather. The Maritime Academy owns a training vessel for "Cadet", which were used to take samples from various points of the coast.

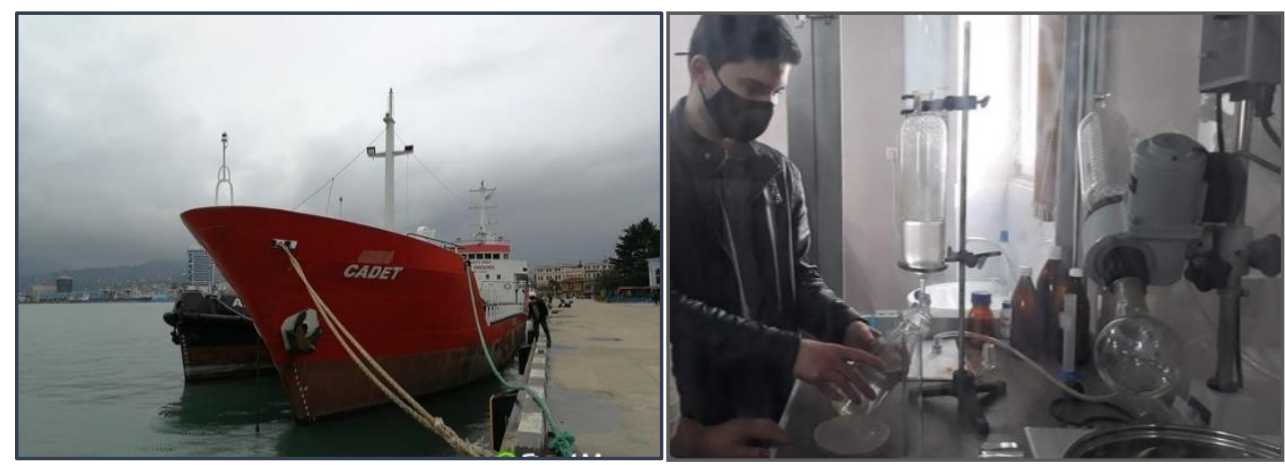

Fig. 3. Students in the process of research

After laboratory research of water samples, we processed the data. Comparing the permissible norms, we made the relevant conclusions. Norms for the content of oil products in wastewater. Some of the Estimated Objects assume the presence of oil products in the effluent. In particular, this applies to enterprises in the automotive service sector - car washes, parking lots, service stations, etc.

And, of course, the content of oil products in the wastewater of oil refineries is inevitable. However, whatever the nature of the facility's activities, it must ensure the purification of its effluents from oil products in accordance with the established standards. The study was conducted on a laboratory apparatus for fractional distillation oil, through which we determined the content of the petroleum product in samples taken at eight different points. The obtained results are presented in Table 2 . The obtained results are compared with the permissible norm, the corresponding conclusion is made.

Table 2. Content of petroleum products $(\mathrm{mg} / \mathrm{L})$

\begin{tabular}{|c|c|c|c|c|c|c|c|}
\hline \multicolumn{8}{|c|}{ (Norm in the sea $-0,05 \mathrm{mg} / \mathrm{L}$, in industrial waters - up to $5 \mathrm{mg} / \mathrm{L}$ ) } \\
\hline \multicolumn{2}{|c|}{ sea buoy mooring } & \multicolumn{2}{|c|}{ Terminal berth } & \multicolumn{2}{|c|}{ Batumi port water area } & \multicolumn{2}{|c|}{ External raid } \\
\hline I & II & $\mathrm{I}$ & II & $\mathrm{I}$ & II & $\mathrm{I}$ & II \\
\hline $0,5-1,8$ & 0,8 & $1,1-2,0$ & 0,3 & $0,5-2,2$ & 0,15 & $1,3-2,7$ & 0,35 \\
\hline Increased. & Increased & Increased. & Increased & Increased & Increased & Increased & Increased \\
\hline \multicolumn{2}{|c|}{ City beach } & \multicolumn{2}{|c|}{$\begin{array}{c}\text { Sea strip near Lake } \\
\text { Ardagan }\end{array}$} & \multicolumn{2}{|c|}{$\begin{array}{l}\text { river. Bartskhani Delta } \\
\text { (at } 50 \mathrm{~m} \text { ) }\end{array}$} & \multicolumn{2}{|c|}{$\begin{array}{c}\text { river Kubistskali } \\
\text { (at } 50 \mathrm{~m} \text { ) }\end{array}$} \\
\hline $0,3-0,8$ & 0,25 & $0,17-0,2$ & 0,1 & $1,2-1,28$ & 0,2 & $0,7-0,9$ & 0,39 \\
\hline Increased & Increased & Increased & Increased & norm & norm & norm & norm \\
\hline
\end{tabular}

We have generalized the result of the verification of Samples taken at eight different points (during I and II flied trips), drew histogram (Figures 4 and 5) and came to the following conclusion:

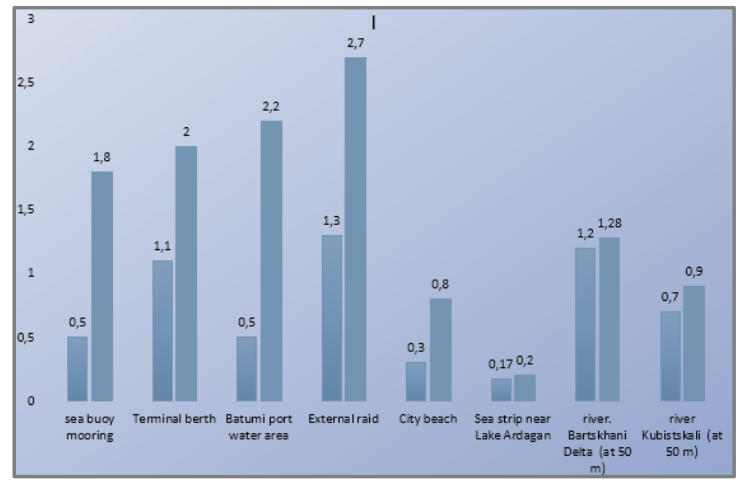

Fig. 4. Bar graph (field I)

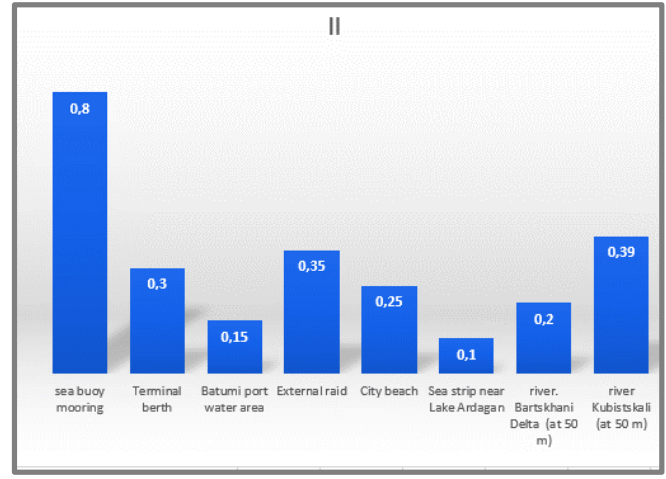

Fig. 5. Bar graph (field II) 
Any ecosystem has the ability to self-clean. This also applies to organic substances of natural origin - oil and fuel oil produced from it, oils, diesel fuel, various types of gasoline, kerosene. They are subject to natural biological destruction, but it takes a very long time and proper conditions, as well as a very long process.

Conclusions. Thus, our field-scientific studies conducted in the Black Sea water area allowed us to determine the nature of the change in the ecological parameters of the Black Sea Batumi water area. In particular, we can assume that the oil pollution of the Batumi coastline is caused by drainage water. Using the results of the research in practice, it is possible to assess the ecological safety of the Batumi port in a complex way and to make a complex, optimal conclusion. Our research is complex in nature. It could not be otherwise, because any kind of pollution is equally harmful to the Black Sea, differing only in the issues of prevention and disposal. One of the reasons for the existing environmental problems is precisely that the well-established approaches and methods of complex management are not being used.

This creates the ground for conflicts between the ecological and economic interests of the society. To achieve a positive effect, it is important to consider the natural environment and economic activities as one system. Finally, by describing the cause-and-effect relationships of the research analysis, we came to the following conclusions:

○ It is known that mechanical and chemical methods of combating pollution with petroleum products can not ensure its complete elimination. Unsustainable consequences and side effects of some methods (subsequent disposal of soils, oil contaminated with oil leachate and oils) significantly increase the environmental improvement measures using them. It is important to introduce modern, environmentally friendly, environmentally and economically viable innovative approaches and technologies. In modern approaches, more and more preference is given to different methods of cleaning the oil-contaminated environment (water, soil, soil and any other type of substrate) [5].

○ Oil mostly pollutes the Black Sea coast, as it is where river confluences, wastewater discharge points, ports and industrial facilities are concentrated. Oil spills from ships pollute not only the coast but also the sea. Almost 111,000 tons of oil are spilled into the Black Sea every year, which, according to official data, is mostly due to negligence. Spilled oil damages the coastal ecosystem, destroys fish spawn and leaflets; This in turn directly affects seabirds, who face another threat: if they are trapped in oil, they lose the ability to fly and dive, can no longer maintain body temperature, their feathers lose their water resistance, and as a result, the birds get sick and die [6].

- Due to the poor condition of the communal infrastructure of the coastal settlements, the sea is polluted with wastewater, and the pollution of the beaches is sometimes close to the almost catastrophic limit. This leads to the impoverishment of the recreational resources of the coastal zone, the reduction of the flow of vacationers and tourists, as well as, ultimately, the deterioration of the socio-economic conditions of the part of the population that is self-employed in tourism and resort services - small hotels, apartment rental, transport services, food and Other [7].

- In addition to oil pollution, visual observations have identified cases of solid waste pollution of rivers and seashores. The Black Sea coast is highly polluted with plastic-containing solid wastes that pose a threat to marine mammals as they swallow them. Too often, foreign bodies are found in the stomachs of dead dolphins on the shore. The debris that floats on the surface carries the waves away from the shore, eventually forming large motive islands of debris in the middle of the sea. The plastic waste is broken down into small pieces, which are eaten by sea animals. As a result of consuming seafood, these wastes get into the human body and are harmful to health - this is the task of our next study [8].

- Air pollution (intense smell of oil) is also noticeable in this zone, which is very noticeable. Due to the oil pollution of the ground, several tens of hectares are practically unusable. From an ecological point of view, oil pollution has quite serious consequences. If we take into account the recreational and tourist importance of the Batumi coastline - the economic consequences of water pollution of beaches and beaches may be even more serious, although these two factors are closely interrelated [9].

○ According to Article IX of the 1992 Convention on the Control of Pollution of the Black Sea (Bucharest Convention), all Black Sea countries are obliged to cooperate with other coastal countries in order to protect the ecological environment of the Black Sea from pollution caused by emergency pollution and disasters. Fight against it. Therefore, in the future, we aim to conduct joint studies on the ecological condition of the Black Sea basin together with the Turkish and Ukrainian naval academies, within the framework of which various unique observations will be made and complex results will be obtained [10]. 


\section{REFERENCES}

1. Diasamidze Mzia, Shotadze Ana. 2021. Renewable energy sources in maintaining environmental stability on the Black Sea coast. $20211^{\text {st }}$ Conference on Traditional and Renewable Energy Sources: Perspectives and Paradigms for the $21^{\text {st }}$ Century (TRESP 2021) E3S Web Conf. V. 250.

2. Diasamidze M., Shotadze A. 2019. Ballast water management and their system progressing. Fundamental and Applied Researches in Practice of Leading Scientific Schools, No 31(1), pp. 58-60.

3. Paresisgvili O., Kvaratskhelia L., Mirzaeva V. 2017. Rural tourism as a promising trend of small business in Georgia: Topicality, capabilities, peculiarities. Annals of Agrarian Science. V. 15. Pp.344-348.

4. Lauren Bradney, Hasintha Wijesekara and others. 2019. Particulate plastics as a vector for toxic trace element uptake by aquatic and terrestrial organisms and human health risk. Environment International, 2019, V.131, 104937.

5. Anthony Chukwunonso Opia. 2019. Biomass as a potential source of sustainable fuel, chemical and tribological materials 0 Overview. SIE 2019: Sustainable Integrated Engineering International Conference. V. 39. Pp.922-928.

6. Elly Kristiani Purwendah, Dewa Gede Sudika Mangku, Aniek Periani. Dispute settlements of oil spills in the Sea towards Sea Environment pollution. Proceedings of the First International Conference on Progressive Civil Society (ICONPROCS 2019). Advances in Social Science, Education and Humanities Research, volume 317. Pp.245-248.

7. Koval V., Mykhno Y., Antonova L., Plekhanov D. Analysis of Environmental factors effect on the development of tourism. Journal of Geology, Geography and Geoecology. V.28. N. 3 (2019). Pp. 445-456.

8. Frederic Gallo, Cristina Fossi, Roland Weber. Marine litter plastics and microplastics and their toxic chemicals components: the need for urgent preventive measures. Gallo et al. Environ Sci Eur (2018).

9. Mikhael P. Croissant and Bulent Aras. 1999. Oil and Geopolitics in the Caspian Sea Region. Book. Westport, Connecticut London.

10. Aylin Ulman, Mustafa Zengin. The Lost fish of Turkey: A Recent history of disappeared species, and commercial fishery extinctions for the Turkish Marmara and Black Sea. Frontiers in Marine Science. 2020. 